УДК 001.891:[66.022.3:637.521.037-021.4]

DOI: $10.15587 / 2313-8416.2014 .31981$

\title{
ДОСЛІДЖЕННЯ ВПЛИВУ КОМПЛЕКСНОЇ ДОБАВКИ «МАЛЬТОВИН» НА ФУНКЦІОНАЛЬНІ ВЛАСТИВОСТІ ЗАМОРОЖЕНИХ М'ЯСНИХ НАПІВФАБРИКАТІВ
}

\author{
(C) І. О. Літвінова, О. М. Савінок
}

В статті наведені дослідження впливу поліфенольної добавки «Мальтовин» на функціональні показники заморожених рубаних напівфабрикатів вироблених за різними технологіями. Аналіз отриманих експериментальних даних дозволяє зробити висновок, щуо використання комплексної добавки в кількості $2 \%$ до маси сировини затримує окиснення ліпідів $і$ сприяє виробництву продукції високої якості та пролонгованого терміну зберігання

Ключові слова: м'ясні заморожені рубані напівфабрикати, комплексна добавка, антиокиснювач, функиіональні властивості, поліфеноли

The article presents the study of the effect of polyphenol additive "Maltovyn" on the functional indices of frozen chopped semi-finished productswith different technologies. Analysis of the experimental data suggests that the use of complex additive in an amount of $2 \%$ by weight of raw retards lipid oxidation and promotes the production of high quality and prolonged shelf life

Keywords: meat frozen chopped semi-finished products, complex additive, antioxidant, functional properties, polyphenols

\section{1. Вступ}

Розвиток м'ясопереробної промисловості в умовах ринкових економічних відносин тісно пов'язаний 3 формуванням принципово нового підходу до виробництва готової продукції, адаптації до об'єктивних зовнішніх факторів. Враховуючи складну ситуацію на вітчизняному ринку м'ясної сировини і періодично виникаючому дефіциту іiі в охолодженому стані, для забезпечення безперервної роботи виробникам м'ясних напівфабрикатів, відповідно до ДСТУ 4437:2005 «Напівфабрикати м'ясні та м'ясо-рослинні посічені», дозволено використовувати заморожену сировину без розморожування при використанні спеціального обладнання (блокорізки, вовчок) під час складання фаршу, внаслідок чого подвійне розморожування не відбувається [1]. Це дозволяє скоротити час на підготовку сировини. На сьогоднішній день дану технологію впровадили провідні підприємства галузі: ТОВ «Три ведмеді», ТОВ «Левада», МПЗ «Легко» ВП ПАТ «Миронівський ЗВКК» та ін.

Незважаючи на використання автоматизованого обладнання, різних технологічних прийомів, які дозволяють випускати продукцію високої якості, в процесі зберігання заморожених напівфабрикатів неминуче хімічне псування. Наслідком цього $\epsilon$ накопичення продуктів окиснення ліпідів, погіршення органолептичних показників i, відповідно, скорочення термінів придатності.

\section{2. Постановка проблеми}

Січені напівфабрикати відносяться до емульгованих м'ясопродуктів, які виготовляються 3 грубоподрібненої сировини, з частково збереженою морфологічною (клітинною) структурою м'яса, малим ступенем диспергування жиру і невеликим вмістом жиру і води в системі [2]. Структура такого продукту може відрізнятися деякою крихкістю i наявністю повітряних порожнин, які інтенсифікують окиснення всередині продукту під дією кисню повітря. Цьому сприяє i збереженість власних ферментів сировини, які проявляють свою активність i при низьких температурах. Каталізаторами окиснення $\epsilon$ також метали змінної валентності, в тому числі залізо у складі гемових пігментів м'яса. На швидкість окиснення впливає i склад основної сировини в продукті. Дуже поширеним видом сировини на сьогоднішній день стало м'ясо птиці механічного дообвалювання (ММДО). Даний вид сировини дуже швидко піддається окиснювальному псуванню за рахунок вмісту в ньому жиру, лімфи, кісткового мозку, тощо.

Найбільш поширеним шляхом вирішення таких завдань м'ясопереробної галузі є застосування різноманітних антиокиснюючих харчових добавок, що дозволяють цілеспрямовано регулювати процеси окиснення ліпідної фракції м'ясних систем. Використовуючи антиокиснювачі, виробники захищають себе не тільки від виникнення даного технологічного дефекту, але й від недотримання температурних режимів при транспортуванні i зберіганні м'ясних напівфабрикатів вже в місцях їх реалізації.

Однак, 3 розвитком сучасних технологій, світове суспільство переорієнтовується на новий рівень сприйняття м'ясної продукції. Саме тому основними напрямками розвитку і трендами сучасної світової м'ясопереробної індустрії $є$ виробництво екологічно безпечних продуктів 3 мінімізованим вмістом харчових добавок. На сьогодні, перед фахівцями м'ясної промисловості стоїть комплекс завдань, серед яких все більше вагомого значення набуває застосування добавок природного походження, які завдяки своєму хімічному складу здатні гальмувати окиснювальні процеси, i, відповідно, підвищувати виробничу ефективність, поліпшувати якість продукції, споживчі і технологічні характеристики. 
Тому метою проведених досліджень було вивчення впливу поліфункціональної добавки «Мальтовин» [3] на функціональні властивості заморожених м'ясних рубаних напівфабрикатів зі значним вмістом жирів. «Мальтовин» - комплексна добавка, до складу якої входе поліфенольний комплекс отриманий шляхом мікрохвильової екстракції з виноградного насіння Vitis vinifera сорту «Ізабелла» та мальтодекстрин.

\section{3. Літературний огляд}

Багато робіт присвячено питанню виробництву м'ясних продуктів 3 пролонгованими термінами придатності за рахунок використання антиокиснювачів природного походження. Окиснювальні процеси знижують харчову цінність м'ясних продуктів за рахунок зміни хімічного складу жирів, при окисненні яких утворюються вільні радикали i низькомолекулярні продукти розпаду - жирні кислоти, в тому числі їх транс-ізомери, альдегіди, кетони, перекиси, які є токсичними речовинами.

Самозвон О. Н. зі співробітниками з Харківського національного університету ім. В. Н. Каразіна [4] вивчали можливість застосування рослинних добавок 3 плодів обліпихи та вільхи в якості антиоксидантів у виробництві м'ясних рубаних напівфабрикатів. Вчені встановили, що із внесенням добавок в модельні фарші котлет покращується соковитість за рахунок збільшення зв'язування води, що пов'язано з хімічним складом рослин. Зберігання зразків упродовж 6 діб призвело до збільшення пероксидного числа контрольного зразка на $15,4 \%$ в порівнянні 3 дослідним. Показник кислотного числа модельних зразків з добавкою був на 10,8 \% менше ніж у контроля. Таким чином, автори довели пригнічення ліполітичних та окиснювальних процесів речовинами, які входять до складу плодів обліпихи і вільхи.

Кочієва І. В., Плотников С. Є., Толкунова Н. М. [5-7] вивчали ефективність використання розторопші для підвищення якості i збільшення термінів зберігання ковбасних виробів і харчових жирів. В проведених дослідженнях автори встановили, що термін придатності сосисок виготовлених 3 м'яса птиці ММДО складав за нормативною документтацією 15 діб при температурі $6{ }^{\circ} \mathrm{C}$. Але вже через 5 діб зберігання значення пероксидного числа контрольних зразків перевищило $0,1 \% \mathrm{~J}_{2}$. Використання екстракту розторопші в максимально допустимій дозі (40 мг/100 г фаршу) дозволило уповільнити небажані процеси - значення пероксидного числа в дослідних сосисках досягло критичного рівня тільки через 10 діб. Антиоксидантний ефект пояснюється наявністю у складі екстракту розторопші фенольних з'єднань, у тому числі флавоноїдів і фенолокислот.

Багато досліджень у даному напрямку провела Гуринович Г. В. [8, 9]. В її роботах увага приділялась застосуванню дигідрокверцетину (ДКВ) для збільшення термінів придатності м'ясних напівфабрикатів. Це з'єднання відноситься до групи вітаміну Р, сировиною для отримання якого можуть бути деревина сибірської модрини, виноград, евкаліпт, пелюстки троянди та інші види рослин. Автором було встановлено, що препарат ДКВ сприяє гальмуванню процесів окиснення жирової фракції м'ясних зразків, що підтверджується меншими значеннями ПЧ в період окиснення i практично повною відсутністю приросту вторинних продуктів окиснення в перші доби зберігання зразків. Навіть порівняльна оцінка антиоксидантної ефективності різних концентрацій ДКВ $(0,02 \% ; 0,08 \% ; 0,2 \%)$ i синтетичного фенольного АО бутилокситолуолу (БОТ) (при рекомендованій концентрації 0,02 \%) показала, що в зразках з додаванням ДКВ в кількості $0,08 \%$ і 0,2 \% спостерігається повне інгибування процесів окиснення упродовж всього часу зберігання. Значення ПЧ зразків при цих концентраціях становили на 97,3 та 98,2 \% нижче, ніж в контролі.

Показники АОА ДКВ та БОТ при рівній концентрації 0,02 \% були близькі: ПЧ для ДКВ - на 85,6 $\%$ нижче, в порівнянні з контролем; ПЧ для БОТ;

- на 80,6 \% нижче контрольного. Отримані результати дали змогу авторам рекомендувати ДКВ в якості ефектив-ної антиоксидантної добавки при виробництві м'ясних продуктів.

\section{4. Визначення впливу комплексної добавки} «Мальтовин» на функціональні властивості січених напівфабрикатів

Для визначення впливу комплексної добавки «Мальтовин» на функціональні властивості січених напівфабрикатів, основною сировиною яких $\epsilon$ ММДО та філе куряче, були проведені порівняльні дослідження напівфабрикатів вироблених за стандартною технологією і рецептурою (позначені на графіках: 3 - контроль 3 охолодженої сировини; 4 - контроль із замороженої сировини) [10] та за власною рецептурою (позначені на графіках: 1 - зразки котлет 3 «Мальтовином» 3 охолодженої сировини; 2 - зразки котлет 3 «Мальтовином» із замороженої сировини) із сировини в різному термічному стані - охолодженої $\left(+4{ }^{\circ} \mathrm{C}\right)$ та заморо-женої $\left(-12^{\circ} \mathrm{C}\right)$. Добавку вносили у дослідні котлети 3 розрахунку 2,0 \% до маси сировини (табл. 1). Зберігали модельні зразки при температурі мінус $18{ }^{\circ} \mathrm{C}$ упродовж восьми місяців. В котлетах одночасно визначали характер змін функціональних властивостей сирих та кулінарнооброблених. Вироби піддавали різній температурній обробці (варінню та смаженню): варили пароповітряною сумішшю при температурі $85{ }^{\circ} \mathrm{C}$ до температури в центрі виробів $74{ }^{\circ} \mathrm{C}$; смажили в розігрітій олії при температурі $150{ }^{\circ} \mathrm{C}$, до температури в товщі напівфабрикату 72-74 ${ }^{\circ} \mathrm{C}$. Контрольованими показниками були кислотне (КЧ) та пероксидне (ПЧ) числа, водневий показник (pH), водозв'язуюча здатність (В33), вміст вологи, вихід після термічної обробки [11].

Враховуючи хімічний склад добавки «Мальтовин» [3] і мету іiі використання, найбільш вагомими показниками на які в першу чергу необхідно було звернути увагу, були кислотне та пероксидне числа ліпідної фракції продуктів. Як видно $з$ рис. 1, $a$, характер залежності накопичення пероксидних з'єднань експоненційний для всіх 
зразків. Накопичення пероксидних з'єднань в зразках із замороженої сировини проходить повільніше, ніж iз охолодженого. Якщо ж порівнювати об'єкти 3 «Мальтовином» і контрольні, то аналізовані значення показників нижчі майже у 3 рази: на кінець терміну зберігання в дослідних зразках із замороженої м'ясної сировини $з$ добавкою показник ПЧ - 0,0095 \% $\mathrm{J}_{2}$, тоді як у контроля за цей час ПЧ досягло значення 0,2 \% $\mathrm{J}_{2} ;$ в контрольних зразках котлет 3 охолодженої сировини ПЧ $-0,24 \% \mathrm{~J}_{2}$, що значно перевершує значення дослідних зразків $з$ добавкою - ПЧ зросло до $0,038 \% \quad \mathrm{~J}_{2}$. Істотна різниця в значеннях пояснюється антиокиснюючою дією поліфенольних сполук, які входять до складу добавки.

Таблиця 1

\begin{tabular}{|l|l|l|}
\hline \multicolumn{4}{|c}{ Рецептурний склад котлет } \\
\hline $\begin{array}{l}\text { Найменування } \\
\text { сировини, прянощів i } \\
\text { матеріалів }\end{array}$ & $\begin{array}{l}\text { Норма кг/на 1 тону } \\
\text { сировини }\end{array}$ \\
\cline { 2 - 3 } & $\begin{array}{l}\text { «олтав- } \\
\text { ські»[10] }\end{array}$ & $\begin{array}{l}\text { «Хаджи- } \\
\text { беївські» }\end{array}$ \\
\hline Філе куряче & 303 & 303 \\
\hline ММО & 303 & 303 \\
\hline Меланж & 34 & 34 \\
\hline Хліб пшеничний & 125 & 125 \\
\hline Молоко коров'яче & 102 & 102 \\
\hline Крупа рисова & 33 & 13 \\
\hline Білок соєвий & 16 & 16 \\
\hline Часник & 24 & 24 \\
\hline Сухарі панірувальні & 51 & 51 \\
\hline Сіль & 12 & 12 \\
\hline $\begin{array}{l}\text { Перець червоний меле- } \\
\text { ний }\end{array}$ & 8 & 8 \\
\hline $\begin{array}{l}\text { Комплексна добавка } \\
\text { «Мальтовин» }\end{array}$ & - & 20 \\
\hline
\end{tabular}

Аналіз зміни кислотного числа показує (рис. 1, б), що внесена добавка значно уповільнює гідроліз жирів. На кінець терміну зберігання в дослідних зразках із замороженого м'яса 3 добавкою показник КЧ складає 0,8 мг КОН, тоді як у контролю за цей час КЧ збільшилось в 2,6 разів і досягло значення - 2,1 мг КОН. В контрольних зразках котлет 3 охолодженої сировини КЧ склало 2,0 мг КОН, що значно перевершує значення дослідних зразків з добавкою: КЧ досягає 1,2 мг КОН. Отримані залежності пояснюються, скоріш за все, властивостями самого мальтодекстрину, який зв'язує вільну вологу в системі, уповільнюючи тим самим процес гідролізу тригліцеридів. Слід відзначити, що напівфабрикати вироблені з охолодженого м'яса вже через 4 місяці не придатні до вживання, із замороженого - через 6 місяців. Дослідні зразки через 8 місяців незначно поступаються свіжим.

При дослідженні водневого показника дослідних напівфабрикатів (рис. 2) було встановлено, що упродовж перших чотирьох місяців зберігання він зростає незалежно від виду зразка, а потім зменшується. Дана тенденція пояснюється тим, що до рецептурного складу входить хліб, рис бланшований, молоко пастеризоване, меланж, соєвий білок. Хімічна взаємодія між інгредієнтами, скоріш за все, і призводить до зростання $\mathrm{pH}$ котлет. Подальше зберігання сприяє кислотному псуванню не м'ясної сировини - при зберіганні молока, меланжу, соєвого білка в замороженому стані відбувається підвищення кислотності цих компонентів, що і призводить до зниження цього показника. Проведення термічної обробки зберігає встановлену тенденцію.

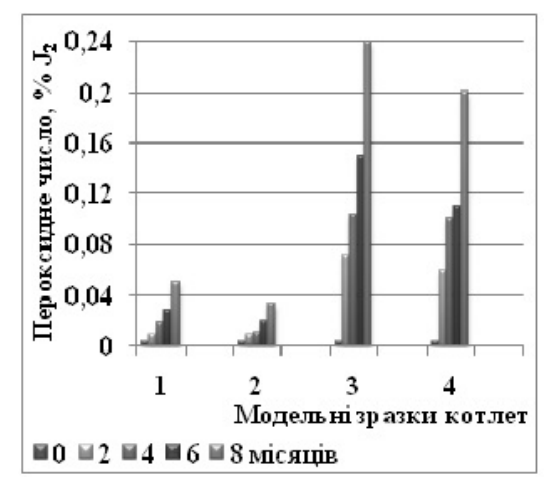

$a$

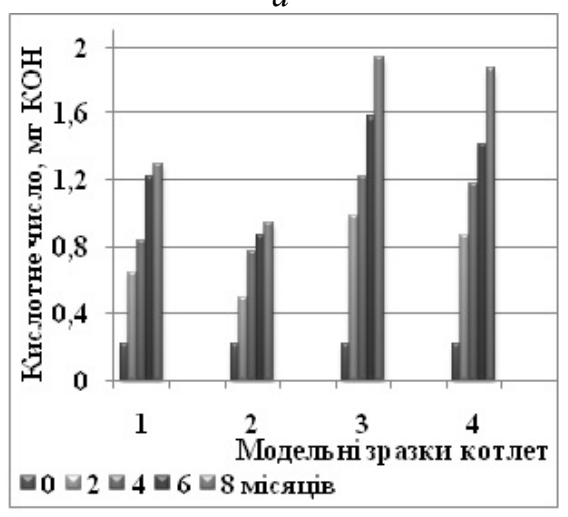

б

Рис. 1. Дослідження зміни чисел ліпідної фракції котлет: $a$ - пероксидного; $\sigma$ - кислотного

Необхідно зауважити, що сирий фарш виробів представляє собою складну полідисперсну систему коагуляційного типу, яка складається переважно 3 білків, жиру та вологи. Вологозв'язуюча здатність (В33) є одним з важливих показників сирого фаршу виробів. В результаті фізико-хімічних, колоїднохімічних процесів, які відбуваються при термічній обробці, частина води і жиру, які зв'язані сирим фаршем, визначаються у вигляді втрат маси. У складі фаршу залишається утримана волога, кількість якої характеризує В33 фаршу. Якщо аналізувати значення В33 (рис. 3), то внесення добавки сприяє збільшенню цього показника. На початку експерименту В33 всіх сирих зразків знаходиться в межах 59 \% (рис. 3, а). На кінець дослідного періоду зберігання даний показник дещо знижується, але в зразках 3 замороженої сировини В33 на 1,5 \% більше, ніж у зразків з охолодженої. Порівнюючи дослідні зразки 3 контролем, слід відзначити, що у них більша В33. Це пояснюється тим, що внесення «Мальтовину» в м'ясну систему призводить до збільшення в ній масової частки високомолекулярних сполук (полісахариду), який набрякає, зв'язуючи вільну вологу. Упродовж зберігання відбувається 
зменшення водозв'язуючої здатності, що пояснюється незначними денатураційними процесами в білковій системі. Аналіз В33 термічно оброблених зразків (рис. 3 б, в) показує схожу кінетику - котлети виготовлені із замороженої сировини мають більші значення показника на 1-2 одиниці, незалежно від рецептурного складу.
Дана тенденція узгоджується із дослідженнями, проведеними Шарпе Г. О. [12]. Отже, крім антиокислювальної дії, «Мальтовин» виконує функцію вологозв'язуючого агента, який забезпечує стабільність фаршевій масі напівфабрикатів при заморожуванні і при термічній обробці.
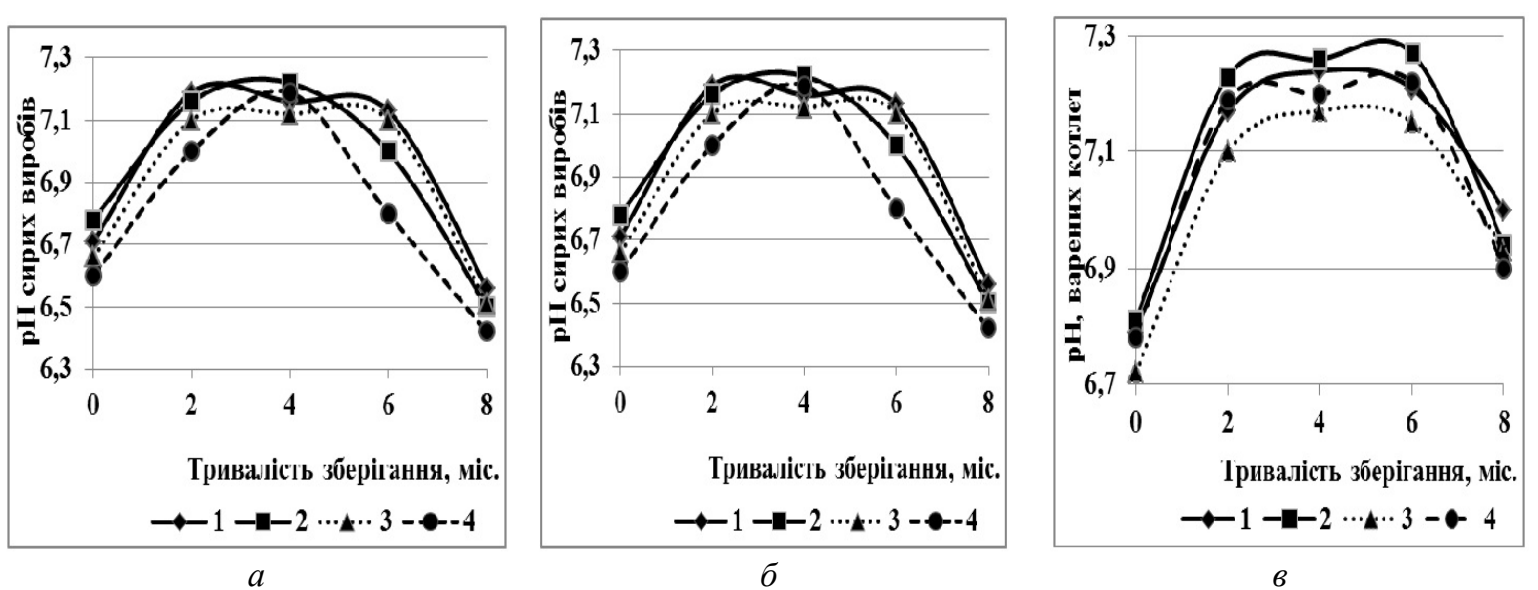

Рис. 2. Кінетична залежність зміни показника рН напівфабрикатів: $a$ - сирих виробів; $\sigma$ - обсмажених виробів; в- варених виробів
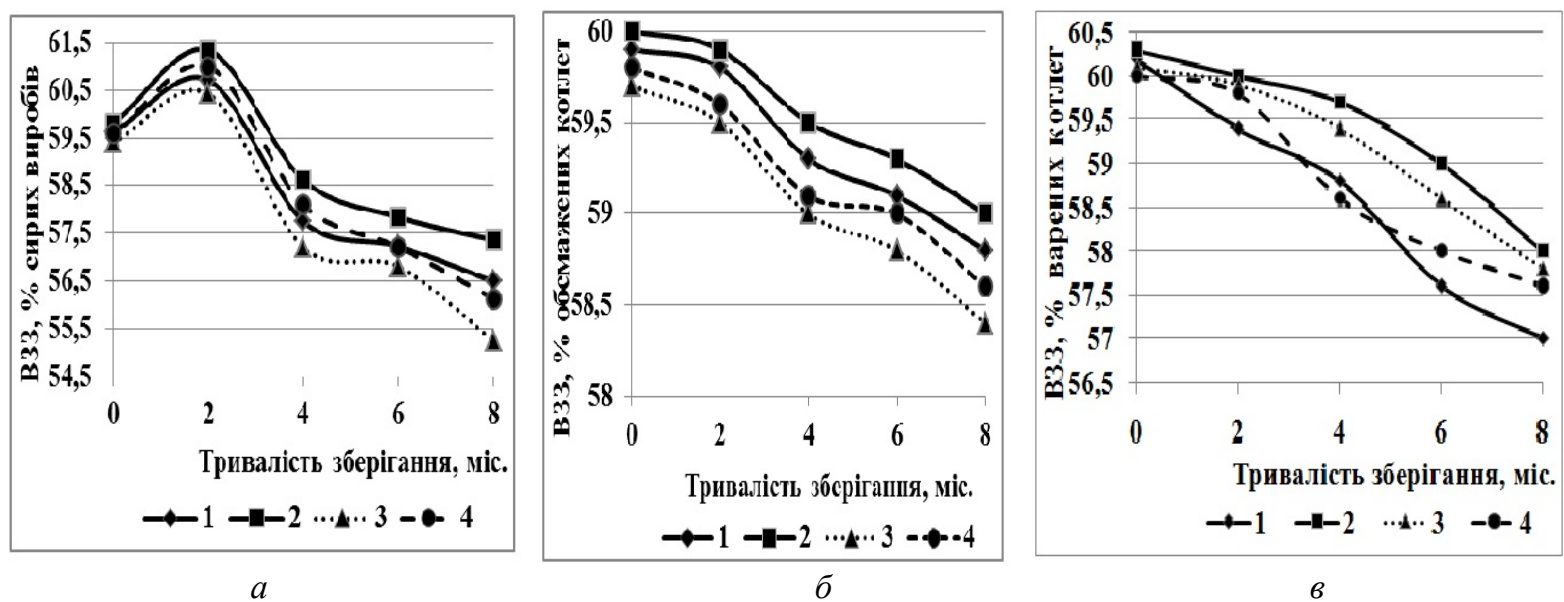

Рис. 3. Кінетична залежність зміни показника В3З напівфабрикатів: $a$ - сирих виробів; $\sigma$ - обсмажених виробів; в- варених виробів

Внесення добавки «Мальтовин» у дослідні зразки незначно змінює вміст вологи (рис. 4). Масова частка вологи - це важливий показник, який впливає як на вихід готового продукту, так і на строки його зберігання. Залежно від виду готових напівфаб-рикатів вміст вологи не повинен перевищувати 60-70 \%.

Масова частка вологи пов'язана напряму з В33 кореляційною залежністю. Як видно із рис. 4, зменшення частки вологи в зразках аналогічне зміні В33. Визначення цього показника в сирих виробах здійснювали після розморожування, що сприяло втраті вологи в дослідних зразках на цьому етапі. Одночасно ці втрати є свідченням слабкого утримування води компонентами продукту. У дослідних зразків на етапі розморожування не спостерігалось відділення рідини від фаршу (при виробництві даної продукції є позитивним фактом, так як виключить відшарування панірувального покриття котлет), тому загальне значення показника дещо більше. Відповід- но, можна припустити, що внесена добавка збільшує частку зв'язаної вологи приблизно на 1 \% для охолоджених виробів і на 1,3 \% для заморожених.

Проведення варіння замороженого продукту без розморожування сприяє більшим втратам вологи саме за рахунок рівномірного і інтенсивного підвищення температури по об'єму продукту. При обсмажуванні продукт прогрівається 3 однієї сторони, що сприяє поступовому розморожуванню верхньої частини і зв'язуванню білками вологи. Крім того, при обсмажуванні утворюється щільна поверхнева шкірочка, яка перешкоджає витіканню вологи 3 продукту. Дане припущення відповідає характерристикам органолептичних показників: смажені котлети мали більш ніжну, соковиту консистенцію в порівнянні з вареними. Якщо ж порівнювати котлети вироблені за різними технологіями, то використання замороженої сировини дозволяє зберегти зв'язану вологу в фаршевій системі. Встановлена особливість 
пояснюється дослідженнями Шарпе Г. О. [12], яка встановила, що розчинність білків тим вища, чим нижча температура $з$ якою м'ясо надходить на заморожування, відповідно вища вологоутримуюча здатність на етапі зберігання і послідуючої термічної обробки. Саме тому вихід варених продуктів, вироблених 3 охолодженої сировини, помітно нижчий,ніж із замороженої (рис. 5).
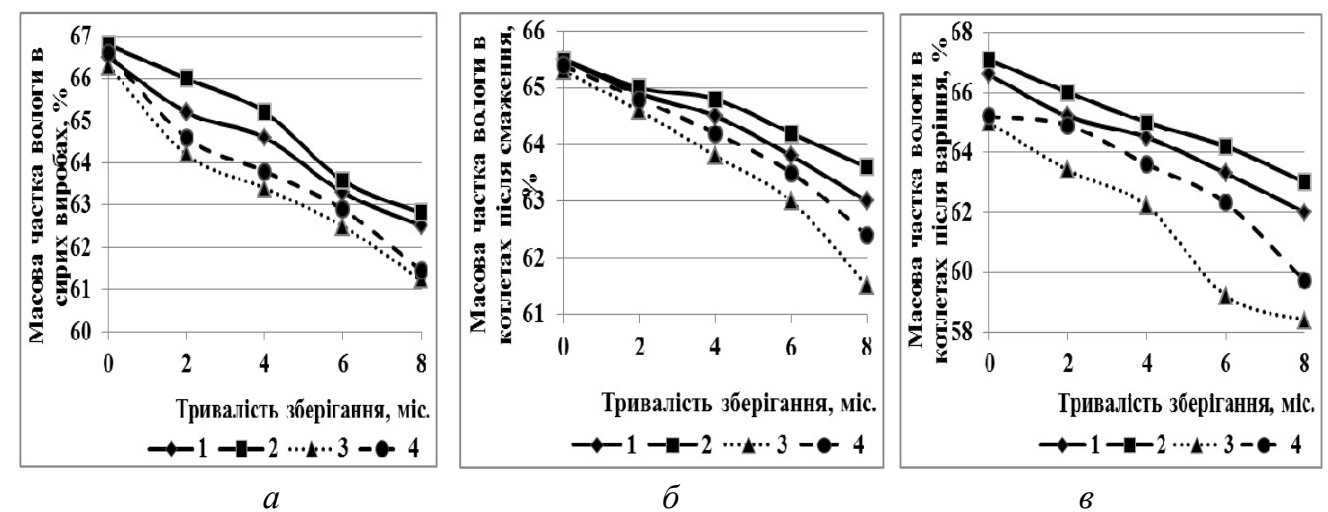

Рис. 4. Кінетична залежність зміни масової частки вологи напівфабрикатів: $a$ - сирих виробів; $\sigma$ - обсмажених виробів; 6 - варених виробів
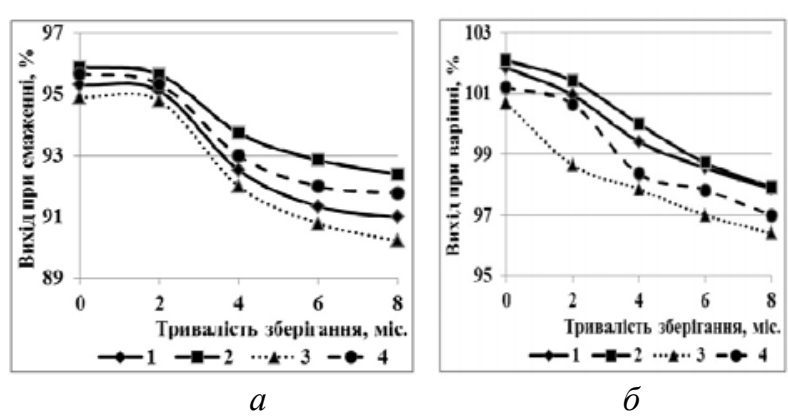

Рис. 5. Кінетична залежність зміни виходу напівфабрикатів після теплової обробки: $a$ - смаження; $\sigma$ - варіння
Отримані дані дозволяють відмітити, що використання добавки в котлетах вироблених iз замороженої сировини забезпечує стійкі показники продукту в процесі низькотемпературного зберігання i термообробки. Компоненти добавки здатні взаємодіяти з білками, що сприяє зв'язуванню вологи і покращенню технологічних характеристик напівфабрикатів.

\section{5. Апробація результатів досліджень}

На основі отриманих результатів були внесені певні зміни в технологію виробництва заморожених січених напівфабрикатів [1, 10], при цьому рекомендований термін зберігання -8 місяців при температурі мінус $18{ }^{\circ} \mathrm{C}$.

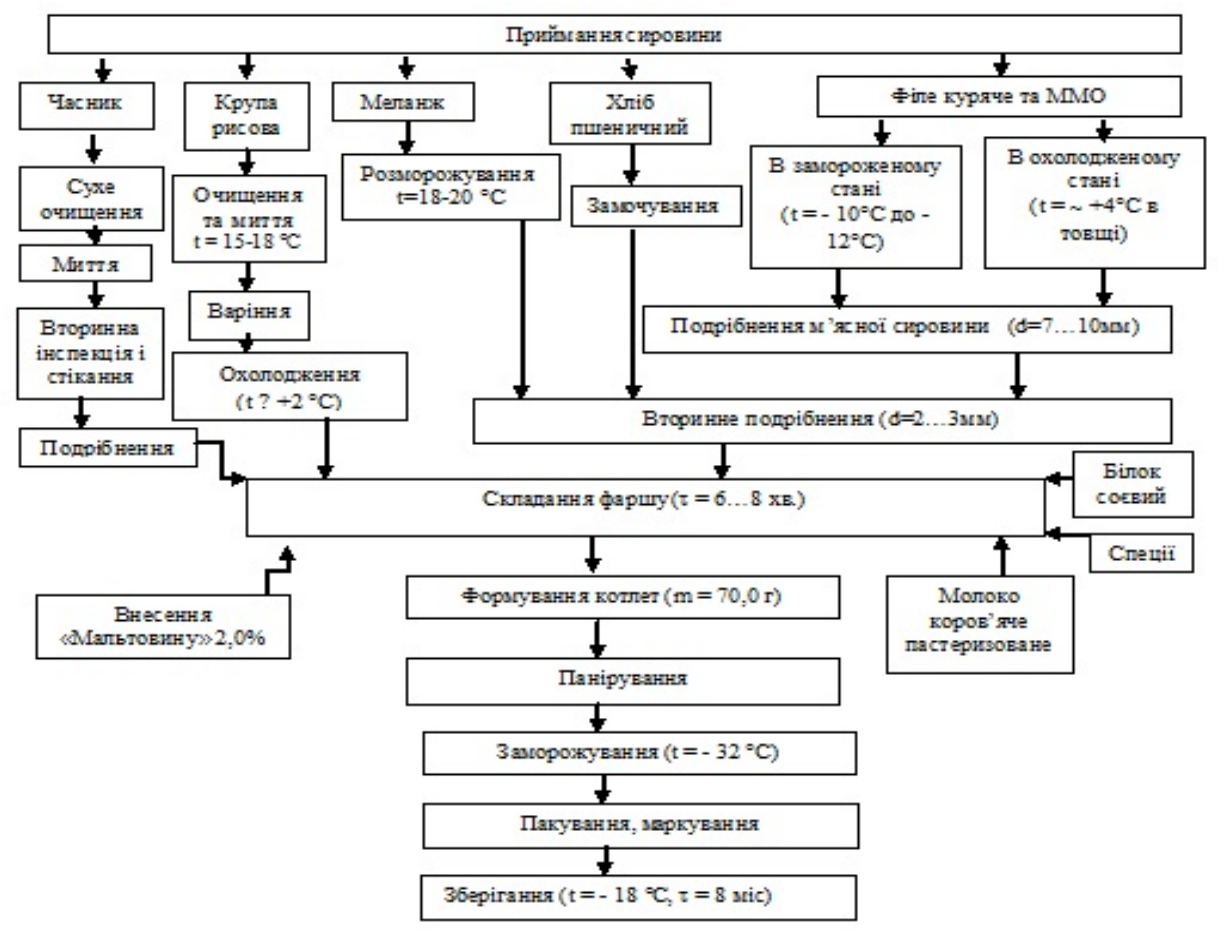

Рис. 6. Технологічна схема виробництва котлет «Хаджибеївських» 


\section{6. Висновки}

В результаті аналізу отриманих експериментальних даних можна зробити висновок, що використання комплексної добавки в кількості $2 \%$ до маси сировини затримує окиснення ліпідів i сприяє виробництву продукції пролонгованого терміну зберігання. Рекомендовані зміни до технології виробництва січених напівфабрикатів дозволять підвищити якість і безпечність продукції, практично виключити процеси окиснювального псування упродовж рекомендованого строку зберігання.

\section{Література}

1. Деклараційний патент України на корисну модель № 71060 від 25.06.2012. Спосіб виробництва котлет [Текст] / Віннікова Л. Г., Шарпе Г. О., Асауляк А. В. - ОНАХТ. Дата подання 26.03.2012, МПК (2012.01) А22С 7/00. Реєстраційний номер заявки u201203568.

2. Жаринов, А. И. Основы современных технологий переработки мяса. В 2 ч. Ч. 1. [Текст] / А. И. Жаринов. Эмульгированные и грубоизмельченные мясопродукты. М.: ПТИ-центр, 1994. - 254 с.

3. Пат. 79879 Україна, МПК ${ }^{51}$ А 23 L 1/29 (2006.01). Спосіб одержання функціональної добавки «Мальтовин» [Текст] / Савінок О. М., Літвінова I. О. - заявник і патентовласник Одеська національна академія харчових технологій. - № 201210153; заявл. 27.08.2012; опубл. 13.05.2013, Бюл. № 9.

4. Самозвон, О. Н. Изучение возможностей применения добавки из плодов ольхи в качестве антиоксиданта при производстве мясных фаршей [Текст] / О. Н. Самозвон О. К. Пивовар, Бондаренко Н. Г. // Луганськ НАУ. - 2008. - № 7. - С. 194-203.

5. Кочиева, И. В. Эффективный способ замедления окислительных процессов [Текст] / И. В. Кочиева, Е. Е. Плотников и др. // Мясная индустрия. -2008 . - № 8. C. 62-63.

6. Кочиева, И. В. Перспективный антиоксидант растительного происхождения [Текст] / И. В. Кочиева, Е. Е. Плотников и др. // Мясная индустрия. -2008 . - № 7. C. $60-62$.

7. Плотников, Е. Е. Растительные антиоксиданты в производстве мясных изделий [Текст] / Е. Е. Плотников, Г. В. Глазова и др. // Мясная индустрия. - 2010. - № 7. C. 26-28.

8. Гуринович, Г. В. Препарат для продления срока годности мясных полуфабрикатов [Текст] / Г. В. Гуринович, К. В. Лисин, Н. Н. Потипаева // Мясная индустрия. 2005. - № 2. - С. 31-33.

9. Гуринович, Г. В. Натуральный антиокислитель для мясных продуктов [Текст] / Г. В. Гуринович, Н. Н. Потипаева // World meat technologies. - 2009. - № 2-3. - С. 36-39.
10. Гущин, В. В. Технология полуфабрикатов из мяса птицы [Текст] / В. В. Гущин, Б. В. Кулишев, И. И. Маковеев, Н. С. Митрофанов. - М.: Колос, 2002. - 119 с.

11. Антипова, Л. В. Методы исследования мяса и мясных продуктов [Текст] / Л. В. Антипова, И. А. Глотова, И. А. Рогов. -М.: КолосС, 2004. - 571 с.

12. Шарпе, А. А. Влияние температурних режимов на функционально-технологические свойства быстрозамороженых мясних полуфабрикатов [Текст] / А. А. Шарпе, Л. Г. Винникова, А. Д. Солецкая, А. В. Зюзько // Харчова наука і технологія. - 2010. - № 2 (11). - С. 68-69.

\section{References}

1. Vinnikova, L. G., Sharpe, G. O., Asaulyak, A. V. (2012). Patent 71060 UA MPK A22C 7/00 (2012.01), Method of production cutlets. Applicant and patent holder Odessa national academy of food technologies. № 201203568; appl. 26.03.2012; publ. 25.06.2012.

2. Jarinov, A. I. (1994). Bases of modern technologies for processing meat. Moscow, PTI-centre, 254.

3. Savinok, O. M., Litvinova, I. O. (2013). Patent 79879 UA MPK ${ }^{51}$ A 23 L 1/29 (2006.01), Method of obsession functional additive "Maltovin". Applicant and patent holder Odessa national academy of food technologies. № 201210153; appl. 27.08.2012; publ. 13.05.2013, Bull. № 9.

4. Samozvon, O. N., Pivovar, O. K., Bondarenko, N. G. (2008). Study of possible use the additive from the fruit of alder as an antioxidant in the production of minced meat, 7, 194-203.

5. Kochieva, I. V., Plotnikov, E. E. et al. (2008). An effective way to slow the oxidative processes. J. Meat Industry, $8,62-63$.

6. Kochieva, I. V., Plotnikov, E. E. et al. (2008). Prospective antioxidant plant origin. J. Meat Industry, 7, 60-62.

7. Plotnikov, E. E., Glazova, G. V. et al. (2010). Plant antioxidants in the production of meat products. J. Meat Industry, 7, 26-28.

8. Hurynovich, G. V., Lisin, K. V., Potipaeva, N. N. (2005). The drug to prolong the shelf life of meat semi-finished. J. Meat Industry, 2, 31-33.

9. Hurynovich, G. V., Potipaeva, N. N. (2009). Natural antioxidant for meat products. J. World meat technologies, 2-3, $36-39$.

10. Gushchin, V. V., Kulishev, B. V., Makoveev, I. I., Mitrofanov, N. S. (2002). The technology of semi-finished poultry meat. Moscow: Kolos, 119.

11. Antipova, L. V., Glotova, I. A., Rogov, I. A. (2004). Research methods of meat and meat products. Moscow: KolosS, 571.

12. Sharpe, A. A., Vinnikova, L. G., Soletskaya, A. D., Zyuzko, A. V. (2010). Influence of temperature to functional and technological properties of frozen meat semi-finished. Food Science and Technology, 2 (11), 68-69.

Рекомендовано до публікаиії д-р техн. наук, проф. Віннікова Л. Г. Дата надходження рукопису 26.11.2014

Літвінова Інна Олександрівна, аспірант, кафедра технології м’яса, риби та морепродуктів, Одеська національна академія харчових технологій, вул. Канатна, 112, м. Одеса, Україна, 65039

E-mail: Litvinnalex@ukr.net

Савінок Оксана Миколаївна, кандидат технічних наук, доцент, кафедра технології м'яса, риби та морепродуктів , Одеська національна академія харчових технологій, вул. Канатна, 112, м. Одеса, Україна, 65039

E-mail: savoksamit@mail.ru 